Journal of Animal and Veterinary Advances 10 (Supplement): 3350-3355, 2011

ISSN: $1680-5593$

(C) Medwell Journals, 2011

\title{
Comparative Efficacy of Three Anesthetic Agents in Himri Barbel, Carasobarbus luteus (Heckel, 1843) under Controlled Conditions
}

\author{
${ }^{1}$ Kaya Gokcek and ${ }^{2}$ Fatih Ogretmen \\ ${ }^{1}$ Faculty of Fisheries and Aquaculture, Mustafa Kemal University, 31200 Iskenderun, Turkey \\ ${ }^{2}$ National State of Hydraulic Works, Adana, Turkey
}

\begin{abstract}
In this study, the efficacy of three anaesthetic agents (Clove oil, 2-phenoxyethanol and benzocaine) was compared in captive-bred Himri barbel, Carasobarbus luteus (Heckel, 1843). The lowest effective concentrations based on the efficacy criteria of complete anesthesia induction within $180 \mathrm{sec}$ and recovery within $300 \mathrm{sec}$ were determined to be $75 \mathrm{mg} \mathrm{L}^{-1}$ (induction $143 \pm 15 \mathrm{sec}$ and recovery time $149 \pm 35 \mathrm{sec}$ ) for clove oil, $500 \mu \mathrm{L} \mathrm{L}^{-1}$ (induction $145 \pm 27 \mathrm{sec}$ and recovery time $57 \pm 16 \mathrm{sec}$ ) for 2-phenooxyethanol and $50 \mathrm{mg} \mathrm{L}^{-1}$ (induction $152 \pm 49 \mathrm{sec}$ and recovery time $88 \pm 24 \mathrm{sec}$ ) for benzocaine. The onset of individual phases of anesthesia and recovery times depended significantly on the concentration of the anaesthetic used $(\mathrm{p}<0.05)$. An inverse exponential relationship was observed between concentrations of anaesthetic and induction time whereas exponential relationships were observed between concentrations and recovery times for all anaesthetic agents evaluated.
\end{abstract}

Key words: Clove oil, benzocaine, 2-phenoxyethanol, induction time, recovery time, Turkey

\section{INTRODUCTION}

Anesthetics play an important role in aquaculture research and production. They are used in weight measurements, selection, broodstock management and in fish health (Summer and Smith, 1990; Kazuf and Siwicki, 2001; Hegyi et al., 2010). Anesthetics, cause different levels of activity in fish. Fish first obtain a state of general anesthesia which ends in a total loss of consciousness. Reflex activity is lost entirely and skeletal muscle tone is also reduced (McFarland, 1960). Overdose or overexposure during treatments reduces breathing and results in low oxygen saturation in blood and ultimately in respiration and circulation disorders (Tytler and Hawkins, 1981). Reduced breathing is an important warning sign that requires termination of the treatment (Hajek and Klyszejko, 2004: Dziaman et al., 2005).

The most commonly used anesthetics in aquaculture are MS-222 (tricaine methane sulphonate), benzocaine (ethly-p-aminobenzoate), methomidate, clove oil and 2-phenoxyethanol (ethylen glycol monophenyl ether) (Velisek et al., 2006, 2011). Currently, only MS-222 is licensed for use in food fish in the USA and the European Union. However, compounds such as 2-phenoxyethanol, clove oil and benzocaine have been evaluated experimentally and are being used in non-food fish and in research (Coyle et al., 2004).
Choosing an appropriate anesthetic depends mainly on its effectiveness in immobilizing fish with good recovery rates (Gilderhus and Marking, 1987; Burka et al., 1997). An ideal anesthetic should possess several attributes such as non-toxic, inexpensive, simple to administer and result in rapid induction and calm recovery (Treves-Brown, 2000). It is often advisable to identify the lowest effective doses of different anesthetics in a specified species as the responses to the same anesthetic may vary considerably among different species (Pawar et al., 2011).

Himri barbel is indigenous cyprinid in the basin of Mesopotamia and highly valuable as food in the region. It is omnivorous species that feeds mainly on detritus (Epler et al., 2001). Its adaptation to earthen ponds has been noticed when it pumped accidently into carp fish ponds located near the Euphrates river (Al-Daham et al., 1991 ) therefore, Himri barbel could be considered as a new species for the regional aquaculture. Some studies have been done on the biology of Himri barbel in the Iraq, Syria and Turkey (Epler et al., 1996; Szypula et al., 2001; Al-Hazzaa, 2005; Gokcek and Akyurt, 2008) but the aquaculture potential of the fish has been identified only recently (Al-Hazza and Hussein, 2003; Hazzaa and Hussein, 2003; Gokcek and Akyurt, 2007; Gokcek, 2008; Gokcek and Tepe, 2009a, b; Gokcek, 2011).

Corresponding Author: Kaya Gokcek, Faculty of Fisheries and Aquaculture, Mustafa Kemal University, 31200 Iskenderun, Turkey 
Given the growing interest in the culture of Himri barbel and lack of detailed practical information on the administration of anesthetics, the overall aim of present study was to determine induction and recovery times of three most common fish anesthetic agents (clove oil, 2-phenoxyethanol and benzocaine) that could be efficiently use in Himri barbel, Carasobarbus luteus (Heckel, 1843), under controlled conditions.

\section{MATERIALS AND METHODS}

Experimental animals: Himri barbel fingerlings were produced from local broodstock in captivity in the aquaculture department of Mustafa Kemal University, Antakya, Hatay, Turkey. About 6 months old fingerlings (average $85 \pm 15 \mathrm{~g}$ ) were transferred to the production unit of National States of Hydraulic Works Department in Adana and held for 2 weeks acclimatization period before the study began.

Anesthetic agents: The anesthetic agents 2phenoxyethanol (ethylene glycol monophenyl ether, Sigma Aldrich Chemic, Germany) (PE), benzocaine (Ethly-p-aminobenzoate, Himedia, India) and clove oil (Biopont, Budapest, Hungary) were used for the present study. Doses of the anesthetic agents were prepared a few minutes before the experiments. Since, clove oil and benzocaine do not dissolve in water (Woody et al., 2002) they were initially diluted in ethanol (ratio of clove oil/benzocaine to ethanol 1:9). PE was initially mixed with water in a reagent bottle and then stirred to disperse the chemical to form small droplets before adding to anesthetic test aquarium.

Induction and recovery stages of anesthetics: The efficacy of three anesthetic agents in fingerling Himri barbel was assessed by testing several doses of each anesthetic. Choice of minimum and maximum doses of each anesthetic was based on previously published information for teleosts (Gomes et al., 2001; Weber et al., 2009). The following doses of each agent were evaluated; clove oil $\left(25,50,75,100\right.$ and $\left.125 \mathrm{mg} \mathrm{L}^{-1}\right), \mathrm{PE}(250,500,750$, 1000 and $\left.1250 \mu \mathrm{L} \mathrm{L}^{-1}\right)$ and benzocaine $(25,50,75$, 100 and $125 \mathrm{mg} \mathrm{L}^{-1}$ ). Five individuals were exposed to five concentrations of each anesthetic totaling 75 individuals. Experiments were prepared in triplicate to verify findings. After 2 weeks of acclimation, the fish were netted from rearing concrete tanks and transferred to the holding aquarium $(200 \mathrm{~L})$ filled with fresh and aerated water in the laboratory conditions. Fish were netted and transferred
Table 1: Signs and stages of anaesthesia in Himri barbel, Carasobarbus luteus

\begin{tabular}{|c|c|}
\hline \multicolumn{2}{|l|}{ Stages } \\
\hline Induction & Recovery \\
\hline $\begin{array}{l}\text { I1:Loss of balance, partiall inhibition } \\
\text { of reactions to external stimuli }\end{array}$ & $\begin{array}{l}\text { R1:Start of movement. Fish still } \\
\text { lay on bottom of the tank }\end{array}$ \\
\hline I2:Total loss of equilibrium. & R2:Regular breathing. Reaction \\
\hline Fish still react to strong stimuli & to strong stimuli.Irregular balance \\
\hline I3:Total loss of reflexes and movement. & $\begin{array}{l}\text { R3:Total recovery of } \\
\text { equilibirium. Reaction to }\end{array}$ \\
\hline $\begin{array}{l}\text { Fish lay on bottom of the tank } \\
\text { I4:Complete cessation of opercula } \\
\text { movements, death }\end{array}$ & $\begin{array}{l}\text { equilibirium. Reaction to } \\
\text { slight stimuli. Normal swimming }\end{array}$ \\
\hline
\end{tabular}

individually to the anesthetic aquarium $(10 \mathrm{~L})$. The induction and recovery time for all anesthetics was measured under same experimental conditions using a digital stopwatch. The water conditions were temperature $23^{\circ} \mathrm{C}, \mathrm{pH} 7.94 \pm 0.56$ and oxygen $5.7 \pm 1.26 \mathrm{ppm}$.

Changes in the physiological status of the anesthetized fish were assessed in four consecutive stages for induction and three stages for recovery described by Theinpoint and Niemegeers with little modifications based on the behavioral response of Himri barbel (Gullian and Villanueva, 2009) (Table 1).

Statistical analysis: A Kruskal-Wallis test was used to assess the differences in induction and recovery times of different concentrations of the same anesthetic agent (Zar, 1999). Regression analyses were used to establish the relationship between dosage and induction time as well as dosage and recovery time. Significance difference was tested at a $5 \%$ level, represented $\mathrm{p}<0.05$. All results were processed and analyzed with the SPSS computer program (SPSS Systems for Windows, Version 13.0).

\section{RESULTS AND DISCUSSION}

Stages of anesthesia: Significant differences $(\mathrm{p}<0.05)$ in the induction and recovery stages at different concentrations of the three anesthetic agents were identified for himri barbel (Table 2). At certain concentration of 2-phenoxyethanol $\left(250 \mu \mathrm{L} \mathrm{L}^{-1}\right)$, all stages of induction could not be attained. This may be due to the concentration applied were too low to reach complete anesthetic induction.

Induction and recovery times of anesthesia: Induction times decreased significantly with increasing doses for all the anesthetic agents evaluated. Induction time (I 3) ranged from $1126 \pm 45 \mathrm{sec}\left(25 \mathrm{mg} \mathrm{L}^{-1}\right)$ to $71 \pm 19 \mathrm{sec}$ $\left(125 \mathrm{mg} \mathrm{L}^{-1}\right)$ for clove oil from $145 \pm 27 \sec \left(500 \mu \mathrm{L} \mathrm{L}^{-1}\right)$ to $32 \pm 3 \mathrm{sec}\left(1250 \mu \mathrm{L} \mathrm{L}^{-1}\right)$ for $\mathrm{PE}$ and from $207 \pm 34 \mathrm{sec}$ 
Table 2: Induction and recovery times $(\mathrm{sec})$ for Himri barbel anaesthetized with five concentrations of three anaesthetic agents. Data are presented as mean \pm SD. Hyphen denotes non-attainment of stage

\begin{tabular}{|c|c|c|c|c|c|}
\hline Stages & 25 & 50 & 75 & 100 & 125 \\
\hline \multicolumn{6}{|c|}{ Clove oil (concentrations $\left(\mathrm{mg} \mathrm{L}^{-1}\right)$ ) } \\
\hline I1 & $83 \pm 21^{\mathrm{a}}$ & $56 \pm 13^{b}$ & $46 \pm 3^{b}$ & $33 \pm 2^{c}$ & $25 \pm 4$ \\
\hline $\mathrm{I} 2$ & $183 \pm 23^{\mathrm{a}}$ & $87 \pm 17^{\mathrm{b}}$ & $77 \pm 13^{b}$ & $60 \pm 5^{c}$ & $41 \pm 8$ \\
\hline I3 & $1126 \pm 45^{\mathrm{a}}$ & $237 \pm 113^{b}$ & $143 \pm 15^{c}$ & $116 \pm 19^{c}$ & $71 \pm 19^{\circ}$ \\
\hline R1 & $37 \pm 18^{\mathrm{a}}$ & $46 \pm 12^{a}$ & $46 \pm 19^{a}$ & $54 \pm 14^{\mathrm{a}}$ & $44 \pm 11^{\circ}$ \\
\hline $\mathrm{R} 2$ & $60 \pm 19^{\mathrm{a}}$ & $106 \pm 37^{b}$ & $69 \pm 29^{9}$ & $90 \pm 19^{a b}$ & $70 \pm 15^{\circ}$ \\
\hline$\underline{\mathrm{R} 3}$ & $132 \pm 20^{\mathrm{a}}$ & $148 \pm 11^{\mathrm{a}}$ & $149 \pm 35^{\mathrm{a}}$ & $198 \pm 8^{b}$ & $287 \pm 8^{b}$ \\
\hline Stages & 250 & 500 & 750 & 1000 & 1250 \\
\hline \multicolumn{6}{|c|}{$\overline{P E}\left(\right.$ concentrations $\left.\left(\mu \mathrm{L} \mathrm{L}^{-1}\right)\right)$} \\
\hline I1 & $128 \pm 11^{\mathrm{a}}$ & $46 \pm 2^{b}$ & $28 \pm 6^{c}$ & $23 \pm 3^{\text {cd }}$ & $18 \pm 1^{\circ}$ \\
\hline $\mathrm{I} 2$ & - & $86 \pm 10^{\mathrm{a}}$ & $62 \pm 9^{b}$ & $43 \pm 6^{c}$ & $26 \pm 4$ \\
\hline I3 & - & $145 \pm 27^{\mathrm{a}}$ & $85 \pm 21^{b}$ & $59 \pm 7^{c}$ & $32 \pm 3$ \\
\hline R1 & - & $25 \pm 5^{\mathrm{a}}$ & $26 \pm 3^{\mathrm{a}}$ & $31 \pm 7^{\mathrm{a}}$ & $57 \pm 22^{b}$ \\
\hline $\mathrm{R} 2$ & - & $41 \pm 6^{\mathrm{a}}$ & $51 \pm 6^{\mathrm{ab}}$ & $49 \pm 12^{\mathrm{ab}}$ & $71 \pm 25^{b}$ \\
\hline R3 & - & $57 \pm 16^{\mathrm{a}}$ & $71 \pm 10^{\mathrm{a}}$ & $79 \pm 8^{\mathrm{ab}}$ & $90 \pm 5^{b}$ \\
\hline Stages & 25 & 50 & 75 & 100 & 125 \\
\hline \multicolumn{6}{|c|}{ Benzocaine (concentrations $\left(\mathrm{mg} \mathrm{L}^{-1}\right)$ ) } \\
\hline I1 & $39 \pm 4^{\mathrm{a}}$ & $31 \pm 4^{b}$ & $26 \pm 2^{c}$ & $20 \pm 2^{\mathrm{d}}$ & $13 \pm 3^{\mathrm{e}}$ \\
\hline $\mathrm{I} 2$ & $75 \pm 12^{\mathrm{a}}$ & $83 \pm 19^{b c}$ & $58 \pm 14^{\text {cd }}$ & $52 \pm 12^{\mathrm{d}}$ & $27 \pm 6^{e}$ \\
\hline I3 & $207 \pm 34^{\mathrm{a}}$ & $152 \pm 49^{b}$ & $72 \pm 8^{c}$ & $62 \pm 12^{c}$ & $32 \pm 4^{\mathrm{d}}$ \\
\hline $\mathrm{R} 1$ & $23 \pm 4^{a}$ & $30 \pm 15^{\mathrm{a}}$ & $35 \pm 3^{\mathrm{a}}$ & $44 \pm 7^{\mathrm{a}}$ & I4 \\
\hline $\mathrm{R} 2$ & $31 \pm 5^{\mathrm{a}}$ & $41 \pm 24^{\mathrm{a}}$ & $47 \pm 4^{\mathrm{a}}$ & $52 \pm 4^{\mathrm{a}}$ & I4 \\
\hline R3 & $69 \pm 21^{\mathrm{a}}$ & $88 \pm 24^{a}$ & $95 \pm 6^{\mathrm{ab}}$ & $114 \pm 16^{b}$ & I4 \\
\hline
\end{tabular}

In all lines, means with different superscripts are significantly different from each other $(\mathrm{p}<0.05)$

( $25 \mathrm{mg} \mathrm{L}^{-1}$ ) to $32 \pm 4 \mathrm{sec}\left(125 \mathrm{mg} \mathrm{L}^{-1}\right.$ ) for benzocaine. Recovery times increased with increasing concentrations of anesthetic agents $(\mathrm{p}<0.05)$. Recovery time ranged from $132 \pm 20 \mathrm{sec}\left(25 \mathrm{mg} \mathrm{L}^{-1}\right)$ to $287 \pm 8 \mathrm{sec}\left(125 \mathrm{mg} \mathrm{L}^{-1}\right)$ for clove oil from $57 \pm 16 \mathrm{sec}\left(500 \mu \mathrm{L} \mathrm{L}^{-1}\right) 90 \pm 5 \mathrm{sec}\left(1250 \mu \mathrm{L} \mathrm{L}^{-1}\right)$ to $90 \pm 5 \mathrm{sec}\left(1250 \mu \mathrm{L} \mathrm{L}^{-1}\right)$ for $\mathrm{PE}$ and from $69 \pm 21 \mathrm{sec}$ ( $\left.25 \mathrm{mg} \mathrm{L}^{-1}\right)$ to $114 \pm 16 \mathrm{sec}\left(100 \mathrm{mg} \mathrm{L}^{-1}\right)$ for benzocaine.

Induction and recovery in relation to concentration: $A$ significant correlation was observed between anesthetic concentration and induction time for all tested anesthetic agents $(\mathrm{p}<0.05)$ whereas scatter plots yielded an inverse exponential relationship (Fig. 1). The regression equations of times to reach 13 and Concentrations (C) of three anesthetic agents in Himri barbel were $\mathrm{I} 3=1260.50 \mathrm{e}^{-0.0183 \mathrm{c}}$ $\left(\mathrm{R}^{2}=0.91\right)$ for clove oil, $\mathrm{I} 3=348.40 \mathrm{e}^{-0.0018 \mathrm{c}}\left(\mathrm{R}^{2}=0.92\right)$ for $\mathrm{PE}$ and $\mathrm{I} 3=332.53 \mathrm{e}^{-0.0183 \mathrm{c}}\left(\mathrm{R}^{2}=0.91\right)$ for benzocaine. Similarly, a significant correlation $(\mathrm{p}<0.05)$ was observed between anesthetic concentration and times to reach R3 for all anesthetic agents whereas scatter plots showed exponential relationships (Fig. 1). The regression equations established for recovery time and concentrations were $\mathrm{R} 3=99.63 \mathrm{e}^{0.0074 \mathrm{c}}\left(\mathrm{R}^{2}=0.72\right)$ for clove oil, $\mathrm{R} 3=53.19 \mathrm{e}^{0.006 \mathrm{c}}\left(\mathrm{R}^{2}=0.93\right)$ for $\mathrm{PE}$ and $\mathrm{R} 3=35.54 \mathrm{e}^{0.0136 \mathrm{c}}$ $\left(\mathrm{R}^{2}=0.96\right)$ for benzocaine.

Post-treatment survival: Himri barbel reared in posttreatment tanks recovered well after the anesthetic experiment. Mortality was observed in the highest dose of benzocaine $\left(1250 \mu \mathrm{L} \mathrm{L}^{-1}\right)$ with the ratio $60 \%$. No other mortality was observed during post-treatment period. Anti-stress agents form an integral component of modern day aquaculture (Pawar et al., 2011). Biological factors include species, the stage of life cycle and age, size and weight, lipid content, body content and disease status. All these factors affect the metabolic rate and therefore, the pharmacokinetics of the anaesthetic compound (Iversen et al., 2003). Environmental factors including temperature and $\mathrm{pH}$ also affect the metabolic rate in fish in addition to changing the uptake across the gills and therefore, increase or decrease the efficacy of an anaesthetic agent (Burka et al., 1997; Ross and Ross, 1999).

In the present study, the induction times decreased significantly with the increasing clove oil, 2phenoxyethanol and benzocaine concentrations $(\mathrm{p}<0.05)$. The results are in agreement with previous studies in teleost fish (Mattson and Riple, 1989; Hseu et al., 1998; Mylonas et al., 2005; Gullian and Villanueva, 2009; Weber et al., 2009; Heo and Shin, 2010). On the other hand, recovery times increased with increasing concentrations of anaesthetic in fingerling Himri barbel. Prolonged recovery with increased anaesthetic dosage has been reported in sockeye salmon (Woody et al., 2002) and cobia (Gullian and Villanueva, 2009). However, decreasing recovery times with and increase in concentration of clove oil and 2-phenoxyethanol for European sea bass and gilthead seabream has been reported by Mylonas et al. (2005). The explanation put 

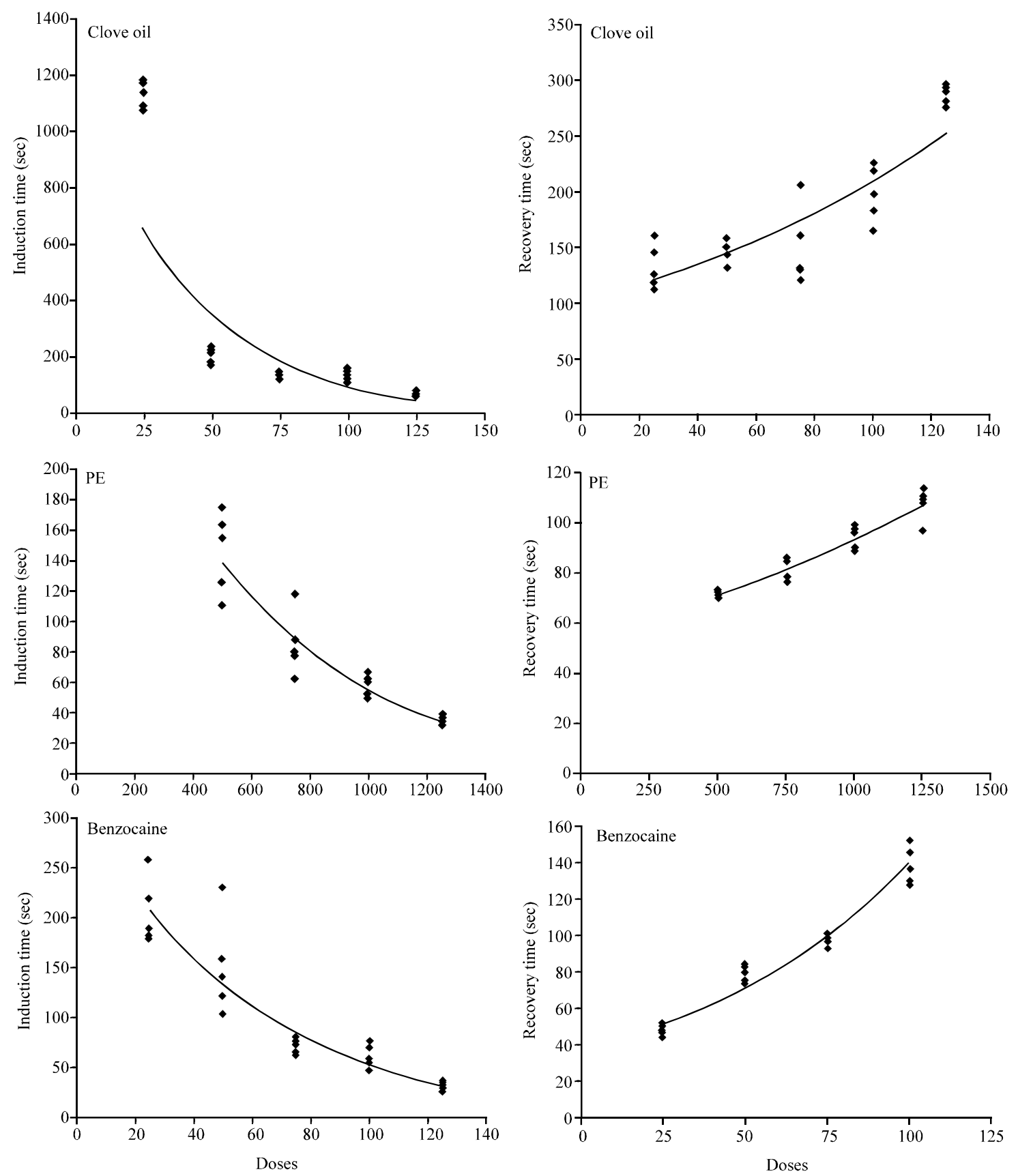

Fig. 1: Induction and recovery times (sec) relation to anaesthetic concentrations for Himri barbel $8 \mathrm{n}=5$ for each trial)

forward by these researchers is that with the highest doses the fish is not contact with the anaesthetic for long which allow faster recovery (Pawar et al., 2011). Also, differences in the physiological responses of fish to the anaesthetic agents also influence this trend (Weber et al., 2009).

According to Marking and Meyer (1985), the anaesthetic agent is considered effective if it produces a complete induction within $180 \mathrm{sec}$ and recovery with $300 \mathrm{sec}$ for fish. In this study, application of clove oil at dose of $75 \mathrm{mg} \mathrm{L}^{-1}, 2$-phenoxyethanol at dose of $500 \mu \mathrm{L} \mathrm{L}^{-1}$ and benzocaine at dose of $50 \mathrm{mg} \mathrm{L}^{-1}$ resulted in quick induction, total immobilization and fast recovery in Himri barbel fingerlings. Although, higher concentrations of three anaesthetic agents achieved shorter induction times, aforementioned doses were 
effective and presented a good margin of safety when compared against the above efficacy criteria. The present study demonstrated that clove oil acts as an anaesthetic in fingerlings of Himri barbel and can be used at concentrations $\geq 75 \mathrm{mg} \mathrm{L}^{-1}$. Although, it results in slightly longer recovery times, the advantages of clove oil is not only smaller cost for aquaculturist but also a lesser polluting effect for the environment. On the other hand, commercial dosage of 2-phenoxyethanol $\left(500 \mu \mathrm{L} \mathrm{L}^{-1}\right)$ was also effective dose for Himri barbel. Benzocaine was effective as anaesthetic for Himri barbel at concentrations $\geq 50 \mathrm{mg} \mathrm{L}^{-1}$. However, at concentration of $125 \mathrm{mg} \mathrm{L}^{-1}$ benzocaine, Himri barbel reached stage I4 with the ratio $60 \%$ during post-treatment period. Mattson and Ripple (1989) found that cod entered stage I3 within $2 \mathrm{~min}$ at dosage of $50 \mathrm{mg} \mathrm{L}^{-1}$ benzocaine. A concentration of $35 \mathrm{mg} \mathrm{L}^{-1}$ was considered an adequate dose to induce fish in rainbow trout (Gilderhus and Marking, 1987). For other fish species, concentration of $80-200 \mathrm{mg} \mathrm{L}^{-1}$ benzocaine was required to induce anesthesia (Dawson and Gilderhus, 1979).

\section{CONCLUSION}

In many countries, the use of fish anesthetics is a matter of concern as there are no specific laws regulating their use (Pawar et al., 2011). Clove oil, 2-phenoxyethanol and benzocaine have been extensively used as an anaesthetic agent in aquaculture of freshwater and marine fishes. Further studies on different life stages, gender, reproduction state and sizes followed by assessments of the effects of anesthetics on haematological profile and respiration rate will advance the understanding of anesthesia of Himri barbel, Carasobarbus luteus.

\section{REFERENCES}

Al-Daham, N.K., A. Y. Al-Dubaikel and N.K. Wahab, 1991. The influence of stocking density on the growth of the common carp (Cyprinus carpio) in the earthen brackish water ponds in Basrah. Basrah J. Agric. Sci., 4: 199-207.

Al-Hazza, R. and A. Hussein, 2003. Stickiness elimination of Himri Barbel (Barbus luteus, Heckel) eggs. Turk. J. Fish. Aquatic Sci., 3: 47-50.

Al-Hazzaa, R., 2005. Some biological aspects of the Himri Barbel Barbus luteus in the intermediate reaches of the Euphrates river. Turk. J. Zool., 29: 311-315.

Burka, J.F., K.L. Hammell, T.E. Horsberg, G.R. Johnson, D.J. Rainnie and D.J. Speare, 1997. Drugs in salmonid aquaculture: A review. J. Vet. Pharmacol. Ther, 20: 333-349.
Coyle, S.D., R.M. Durborow and H.J. Tidwell, 2004. Anaesthetics in Aquaculture. SRAC Publication, Texas.

Dawson, V.K. and P.A. Gilderhus, 1979. Ethyl-pAminobenzoate (Benzocaine): Efficacy as an Anesthetic for Five Species of Freshwater Fish. U.S. Dept. of the Interior, Fish and Wildlife Service, Washington, USA.

Dziaman, R., B. Klyszejko and G. Hajek, 2005. The effect of MS-222 on the cardiac and respiratory function and behaviour of common carp, Cyprinus carpio L., during general anaesthesia. Acta Ichthyol. Piscatoria, 35: $125-131$.

Epler, P., M. Sokolowskja-Mikolajczyk, W. Popek, K. Bieniarz, D.E. Kime and R. Bartel, 1996. Gonadal development and spawning of Barbus sharpeyi, Barbus luteus and Mugil hishni in fresh and saltwater lakes in Iraq. Arch. Polish Fish., 4: 113-124.

Epler, P., R. Bartel, J. Chyp and J.A. Szczerbowski, 2001. Diet of selected fish species from the Iraqi lakes Tharthar, Habbaniya and Razzazah. Arch. Polish Fish., 9: 211-223.

Gilderhus, P.A. and L.L. Marking, 1987. Comparative efficacy of 16 anesthetic chemicals on rainbow trout. North Am. J. Fish. Manage., 7: 288-292.

Gokcek, C.K. and I. Akyurt, 2007. The effect of stocking density on yield, growth and feed efficiency of Himri Barbel (Barbus luteus) nursed in cages. Israeli J. Aquacult., 59: 99-103.

Gokcek, C.K. and I. Akyurt, 2008. Age and growth characteristics of Himri barbel (Barbus luteus Heckel, 1843) in Orontes river, Turkey. Turk. J. Zool., 32: 461-467.

Gokcek, C.K. and Y. Tepe, 2009a. An alternative species for traditional carp polyculture in Turkey: Initial growing period. J. Fish. Sci., 3: 18-23.

Gokcek, K. and Y. Tepe, 2009b. The effects of feeding level and stocking density on the growth and feed efficiency of Himri Barbel fry, Barbus luteus (Heckel, 1843). Turk. J. Vet. Anim. Sci., 33: 21-25.

Gokcek, K., 2011. Tilapia, Oreochromis niloticus (Linnaeus, 1758) and himri barbel, Carasobarbus luteus (Heckel, 1843), duoculture in net cages. J. Anim. Vet. Adv., 10: 1102-1105.

Gokcek, K.C., 2008. Effect of feeding frequency on the growth and survival of himri barbel barbus luteus (Heckel, 1843), fry under laboratory conditions. Pak. J. Nutr., 7: 66-69.

Gomes, L.C., A.R. Chiparri-Gomes, N.P. Lopes, R. Roubach and C.A.R.M. Araujo-Lima, 2001. Efficacy of benzocaine as an anesthetic in juvenile tambaqui Colossoma macropomum. J. World Aqua. Sco., 32: 426-431. 
Gullian, M. and J. Villanueva, 2009. Efficacy of tricaine methanesulphonate and clove oil as anaesthetics for juvenile cobia Rachycentron canadum. Aquacult. Res, 40: 852-860.

Hajek, G. and B. Klyszejko, 2004. The effects of prospiscin (etomidate) on the behavior, heart rate, and ventilation of common carp, Cyprinus carpio L. Acta Ich. Piscat., 34: 129-143.

Hazzaa, R. and A. Hussein, 2003. Initial observations in himri Barbus luteus heckel) propagation. Turk. J. Fish. Aquat. Sci., 3: 41-45.

Hegyi, A., B. Urbanyi, M. Kovacs, K.K. Lefler, J. Gal, G.Y. Hoitsy and A. Horvath, 2010. Investigation of potential stress parameters in rainbow trout (Onchorhynchus mykiss). Acta Bio. Hung., 61: 24-32.

Heo, G.J. and G. Shin, 2010. Efficacy of benzocaine as an anaesthetic for Crucian carp (Carassius carassius). Vet. Anaesth. Analg., 37: 132-135.

Hseu, J.R., S.L. Yeh, Y.T. Chu and Y.Y. Ting, 1998. Comparison of efficacy of five anesthetics in goldlined sea bream, Sparus sarba. Acta Zool. Taiwanica, 1: 35-41

Iversen, M., B. Finstad, R.S. MacKinley and R.S. Eliiassen, 2003. The efficacy of metomidate, clove oil, Aqui-S and Benzoak as anaesthetics in atlanti salmon (Salmo salar L.) smolts and their potential stress-reducing capacity. Aquaculture, 221: 549-566.

Kazuf, K. and A.K. Siwicki, 2001. Propiscin: A safe new anaesthetic for fish. Arch. Polish. Fish., 9: 183-190.

Marking, L.L. and F.P. Meyer, 1985. Are better anesthetics needed in fisheries?. Fisheries, 10: 2-5.

Mattson, N.S. and T.H. Riple, 1989. Metomidate, a better anaesthetic for cod (Gadus morhua) in comparison with benzocaine, MS-222, chlorobutanol and phenoxyethanol. Aquauculture, 83: 89-94.

McFarland, W.N., 1960. The use of anaesthetics for the handling and the transport of fishes. Calif Fish Game, 46: 407-431.

Mylonas, C.C., G. Cardinalettia, I. Sigelakia and A. Polzonetti-Magni, 2005. Comparative efficacy of clove oil and 2-phenoxyethanol as anesthetics in the aquaculture of European sea bass (Dicentrarchus labrax) and gilthead sea bream (Sparus aurata) at different temperatures. Aquaculture, 246: 467-481.
Pawar, H.B., S.V. Sanaye, R.A. Sreepada, V. Harish, U. Suryavanshi and Z.A. Ansari, 2011. Comparative efficacy of four anaesthetic agents in the yellow seahorse, Hippocampus kuda (Bleeker, 1852). Aquaculture, 311: 155-161.

Ross, L.G. and B. Ross, 1999. Anesthetics and Sedative Techniques Fro Aquatic Animals. Blackwell Sci., Oxford, Pages: 159.

Summer, F.R.C. and L.S. Smith, 1990. Anesthesia, Surgery and Related Techniques. In: Methods for Fish Biology, Schreck, C.B. and P.B. Moyle (Eds.). American Fisheries Society, Bethesda, MD., pp: 213-272.

Szypula, J., P. Epler, R. Bartel and J.A. Szczerbowski, 2001. Age and growth of fish in lakes Tharthar, Razzazah and Habbaniya. Arch. Polish Fish., 9: 185-197.

Treves-Brown, K.M., 2000. Anaesthetics in Applied Fish Pharmacology. Kluwer Academic Publishers, Dordrecht, Netherlands, pp: 206-217.

Tytler, P. and A.D. Hawkins, 1981. Vivisection Anesthetics and Minor Surgery. In: Aquarium Systems, Hawkins, A. (Ed.). Academic Press, New York, pp: 247-278.

Velisek, J., A. Stara, Z.H. Li, S. Silovska and J. Turek, 2011. Comparison of effects of four anaesthetics on blood chemical profiles and oxidative stress biomarkers in rainbow trout. Aquaculture, 310: 369-375.

Velisek, J., T. Wlasow, P. Gomulka, Z. Svobodova, L. Novotny and A. Ziomek, 2006. Effects of clove oil anaesthesia on catfi sh (Silurus glanis L.). Acta Vet. Brno., 75: 99-106.

Weber, R.A., J.B. Peleteiro, L.O.G. Martin and M. Aldegunde, 2009. The efficacy of 2phenoxyethanol, metomidate, clove oil and MS-222 as anaesthetic agents in the Senegalese sole (Solea senegalensis Kaup 1858). Aquaculture, 288: 147-150.

Woody, C.A., J. Nelson and K. Ramstad 2002. Clove oil as an anaesthetic for adult sockeye salmon: Field trials. J. Fish. Biol., 60: 340-347.

Zar, J.H., 1999. Biostatistical Analysis. 4th Edn., Prentice-Hall, New Jersy, USA., Pages: 469. 